\title{
Ants (Hymenoptera: Formicidae) Attracted to Rabbit Carcasses in Three Different Habitats
}

\author{
Ashraf Mashaly ${ }^{1,3}{ }^{3}$, Mostafa SharaF ${ }^{2}$, Medghom al-Subeal ${ }^{1}$, Fahd Al-MeKhlafi, Abdulrahman AldaWood ${ }^{2}$, Gail Anderson ${ }^{4}$ \\ 1 - Department of Zoology, College of Science, King Saud University, Riyadh, Saudi Arabia \\ 2 - Plant Protection Department, College of Food and Agriculture Sciences, King Saud University, Riyadh, Saudi Arabia \\ 3 - Department of Zoology, Faculty of Science, Minia University, El-Minia, Egypt \\ 4 - School of Criminology, Simon Fraser University, University Drive, Burnaby, BC, Canada
}

\section{Article History}

\section{Edited by}

Evandro N. Silva, UEFS, Brazil

Received $\quad 14$ February 2018

Initial acceptance 31 March 2018

Final acceptance 02 June 2018

Publication date 02 October 2018

\section{Keywords}

Ants, decomposition, forensic entomology, Riyadh, Saudi Arabia.

\section{Corresponding author}

Ashraf Mashaly

Department of Zoology, College of Science

P. O. Box 2455, King Saud University

Riyadh 11451, Saudi Arabia.

E-Mail: mmashely@ksu.edu.sa

\begin{abstract}
This study reports the ant species that were attracted to rabbit carcasses in three different habitats (agricultural, desert, urban) in the city of Riyadh, Saudi Arabia from May to July 2014. Rabbit carcasses were used as a model for decomposition. Carcasses were categorized as exposed, clothed, shaded and burnt. A total of 726 ants belonging to three subfamilies and 14 species were collected during the decomposition process. Trichomyrmex mayri (Forel) was the only ant species attracted to the carcasses placed in the desert site. At the agricultural site, there was one ponerine species, five formicine species, and three myrmicine species were attracted, while at the urban site, five formicine species and one myrmicine species were recorded. The agricultural site attracted the highest number of ants. In contrast, the desert site attracted the lowest number of ants. Tr. mayri was the most prevalent species occurring in both the agricultural and desert sites. The bloated stage of decomposition attracted the highest number of ants followed by the decay, fresh and dry stages, respectively. Clothed carcasses attracted the highest number of ants followed by the exposed and burnt carcasses, respectively. The shaded carcasses attracted the fewest number of ants. This study found that ants are attracted to carcasses at all stages of decomposition and are common components of the necrofauna of central Saudi Arabia.
\end{abstract}

\section{Introduction}

The combined weight of all living ants has been estimated to constitute half the mass of all extant insects (Sleigh, 2003) and individual ants outnumber most other terrestrial animals (Taylor, 2007). Ant species constitute the largest family in the order Hymenoptera, which, in itself, is the third most numerous order of insects after Diptera (true flies) and Coleoptera (beetles) (Taylor, 2007). Ants are one of the most successful groups of insects, exploiting a variety of habitats around the world (Sleigh, 2003) and are absent from only a few areas, even able to exist in extreme arid and hot desert environments. For example, species of the genus Cataglyphis have developed very long legs so as to lift their bodies up off the substrate, together with hairs which reflect light, allowing them to cope with air temperatures as high as $55^{\circ} \mathrm{C}$ (Keller \& Gordon, 2009; Shi et al., 2015).

Ants can have an impact on overall carrion ecology. Catts and Haskell (1990) reported that ants may feed directly on carcasses or prey on other arthropods associated with carcasses. Ants can also accelerate the decomposition process by producing abrasions or injuries facilitating the attraction of other species of necrophagous insects (Gunn, 2006). Sometimes, these ants cause lesions that can be misinterpreted as premortem mutilations, which can lead to errors in forensic analyses (Moretti \& Ribeiro, 2006; Campobasso et al., 2009; Lindgren et al., 2011; Moretti et al., 2011). For example, the Red Imported Fire Ant, Solenopsis invicta (Buren) can 
cause damage to tissue that could be mistaken for pre-mortem burns (Byrd \& Castner, 2001). In some instances, initial colonization of dipterans or other organisms on carcasses may be delayed by two to three days due to the high predation rate of fly eggs by ants (Byrd \& Castner, 2001); these instances appear more common if the carcass is located close to an ant nest. For example, acrobat ants of the genus Crematogaster feed on immature stages of many flies.

The literature shows that there are a number of factors that may affect insect colonization of carcasses, including habitat, the presence or absence of clothing, sun exposure and whether the carcass has been burned. Clothing may affect insect diversity, abundance, and feeding activities and consequently may increase the decomposition rate, by offering protection from ambient conditions and predators (Mann et al., 1990; Dillon, 1997; Campobasso et al., 2001; Card et al., 2015). It has been reported that carcasses exposed to the sun decompose faster than ones in the shade, as well as exhibiting different patterns of insect succession (Joy et al., 2006; Sharanowski et al., 2008; Castro et al., 2011). Heo et al. (2009) studied ant succession in Malaysia and noted differences in species attracted to burned and unburned pig carcasses.

In Saudi Arabia only one published study recorded ants attracted to the carcasses, where Shaalan et al. (2017) recorded Pheidole megacephala (F.) in Al-Ahsaa Oasis, in the Eastern Region of the Kingdom. Hence, the importance of the present article is that it is the first to provide a qualitative assessment of the major ants taxa attracted to decomposing carcasses placed in an agricultural area, a typical desert site, and an urban site, in the city of Riyadh using four carcass treatments, namely, exposed, clothed, shaded and burnt.

\section{Material and Methods}

Study sites

The study was conducted in three different habitats: an urban area $\left(24^{\circ} 43^{\prime} 40.89^{\prime \prime} \mathrm{N}, 46^{\circ} 36^{\prime} 54.92^{\prime \prime}\right.$ E) located within $200 \mathrm{~m}$ of human dwellings; an agricultural area (244'36.54" N, 46³3'45.12" E,) with many palm trees (Phoenix canariensis Chabaud) and typical grasses (Setaria verticillata L.), where the nearest human dwelling was approximately $1 \mathrm{~km}$ from the study site, and a desert site (244' $36.54^{\prime \prime}$ N, 46 33'45.12" E) with a substrate made up primarily of hard packed dry rock, where the nearest human dwelling was approximate $4.5 \mathrm{~km}$ away. The experiment was repeated three times during May to July 2014. Temperatures (Fig 1) were recorded using a Lascar EL-USB-2 data logger. Each data logger was attached to the top of a $1 \mathrm{~m}$ vertical post at the centre of each of the experimental sites.

\section{Carcasses}

Most carrion research utilizes pig (Sus scrofa L.) carcasses, but pigs cannot be used in KSA. Therefore, thirtythree $(\mathrm{n}=33)$ live mature rabbits, Oryctolagus cuniculus (L.), were obtained. Each animal was euthanized using chloroform inhaled in a chamber. The treatment of the rabbits followed the regulations of the Animal Research and Ethics Committee (FU-CARE). Several studies in KSA and other countries have used rabbit carcasses to study the process of decomposition and insect succession; for example, Tantawi et al. (1996); Abou Zied (2014); Silahuddin et al. (2015) and Shaalan et al. (2016). Each rabbit weighed $1.57 \pm 0.44 \mathrm{~kg}$. At each of the agricultural and urban sites, twelve rabbits were divided into three groups of four. At the desert site, nine rabbits were divided into three groups of three, since the experiment in shaded conditions was excluded from the desert habitat. At each study site, rabbit carcasses were arranged in a regular, symmetrical pattern of three parallel rows, with four carcasses in each row, with a $2 \mathrm{~m}$ space between rabbits. Three rabbit carcasses (one from each row) were partially burned at the site using wood without accelerant to a level 2 on the CrowGlassman Scale (Glassman \& Crow, 1996). Three carcasses were clothed in a white cotton short-sleeved clean T-shirt to simulate a clothed body. Three rabbit carcasses were placed in a shaded area under a tree which was $2{ }^{\circ} \mathrm{C}$ cooler than in direct sun and three rabbits were exposed, with no additional treatment. Each carcass was placed inside a steel cage $(55 \mathrm{~cm}$ $\mathrm{x} 40 \mathrm{~cm} \times 24 \mathrm{~cm})$ to exclude scavengers. The cages did not have a bottom, allowing the carcasses to be in direct contact with the ground. All carcasses were monitored from initial exposure to almost complete skeletonization. Four stages of decomposition were recognized following Payne (1965), Gennard (2007) and AbouZied (2014), namely fresh, bloated, active decay, and dry remains.

\section{Sampling and identification}

Each carcass was examined for 10 minutes hourly from 9 AM to 4 PM, for the first three days, then daily, at 9 am from the fourth day after death, until the carcasses were almost completely skeletonized. Ants were collected with forceps (for the running ants around the carcasses) from all parts of the rabbit carcasses including underneath

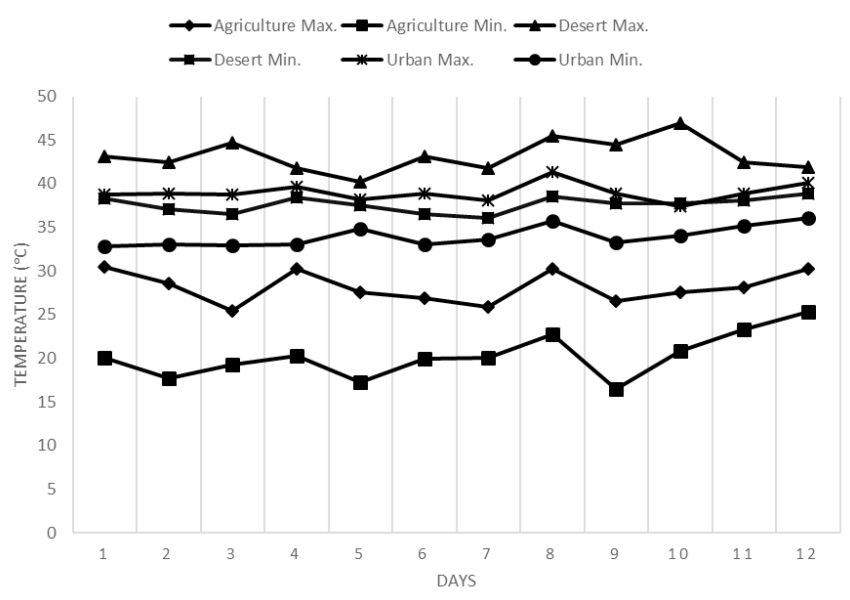

Fig 1. Summary of the temperature data at the study sites over the duration of the experiment (May to July 2014). 
the carcases. Pitfall traps were also used to reduce carcass disturbance and to continue to monitor beyond the active collection times. Collection was carried out without depleting the ants on the carcass so as to avoid any impact on the next collection. All ant specimens were preserved in $70 \%$ ethanol. The specimens were identified by the second author (M. R. Sharaf) using Collingwood (1985), Hölldobler and Wilson (1990), Bolton (1994) and Collingwood and Agosti (1996). Voucher specimens of each species are deposited at the King Saud University Museum of Arthropods, King Saud University, Riyadh, Saudi Arabia.

\section{Statistical analysis}

Significant differences in diversity (as quantified by the number of ant species) among habitats, decomposition stages and carcass status was evaluated using the KruskalWallis test (Minitab 2017).

\section{Results}

In our study, the rabbit carcasses attracted different species of ants during the decomposition stages. The carcasses in the desert and urban sites progressed from the fresh to the dry remains stage in six days and in approximately 12 days at the agricultural site (Fig 2). Ants were observed feeding on immature insects on the rabbit carcasses.
Ants were attracted significantly to the carcasses at the agricultural site (454 ants) than the urban and desert sites, with 165 ants and 106 ants, respectively. The abundance of ants varied between treatments and sites. By far, the greatest number of ants were collected from the carcasses at the agricultural site and ants were present in all decompositional stages on the clothed and exposed carcasses and in the fresh, bloat and decay stages on the shaded and burnt carcasses, but were not present during the dry remains stage of these treatments. At the desert site, ants were much rarer in general. The urban site was the only one of the three in which ants were collected in all decay stages and on all treatments, although far fewer were collected than in the agricultural habitat.

Table 1 presents a summary of ant species collected at the three different sites from the rabbit carcasses. Only one species, Trichomyrmex mayri (Forel) (Myrmicinae) was collected from carcasses placed at the desert site. Nine species of ants belonging to three subfamilies were found on carcasses placed at the agricultural site, Brachyponera sennaarensis (Mayr), Camponotus aegyptiacus (Emery), C. maculatus (Fabricius), C. sericeus (Fabricius), C. xerxes (Forel), Cataglyphis semitonsa (Santschi), Pheidole sp., Tr. mayri, and Tetramorium lanuginosum (Mayr). At the urban site, six species were attracted, C. aegyptiacus, C. sericeus, Ca. holgerseni (Collingwood and Agosti), Ca. livida (André), Ca. savignyi (Dufour) and Monomorium venustum (Smith).

\begin{tabular}{|c|c|c|c|c|c|c|c|c|c|c|c|c|c|c|}
\hline \multirow{2}{*}{ Habitat } & \multicolumn{14}{|c|}{ Post-mortem interval (Days) } \\
\hline & 1 & 2 & 3 & 4 & 5 & 6 & 7 & 8 & 9 & 10 & 11 & 12 & 13 & 14 \\
\hline \multicolumn{15}{|c|}{ Agricultural } \\
\hline \multicolumn{15}{|c|}{ Urban } \\
\hline \multicolumn{15}{|l|}{ Desert } \\
\hline & & & & & & ated & & & & ry & & & & \\
\hline
\end{tabular}

Fig 2. The duration of the decomposition stages in the three different habitats.

Ant species were very habitat specific, with only $T r$. mayri observed in two different sites (agricultural and desert). At the agricultural and urban sites, ants were attracted to all decomposition stages, but at the desert site, ants were active only during the bloated and decay stages. Also, at the agricultural and urban sites, ants were attracted to all types of carcasses although, at the urban site, Ca. livida was the only ant species attracted to all types of carcasses and during all stages of decomposition.

At the agricultural site, $T r$. mayri was attracted in high numbers followed by $T$. lanuginosum, $C$. sericeus and $C$. xerxes. Cataglyphis holgerseni, Ca. livida, Ca. savignyi and M. venustum were not attracted to the carcasses at this site (Fig 3). At the desert site, Tr. mayri was the only ant species attracted in large numbers in comparison with other species at the other sites (Fig 3). At the urban site, Ca. savignyi was

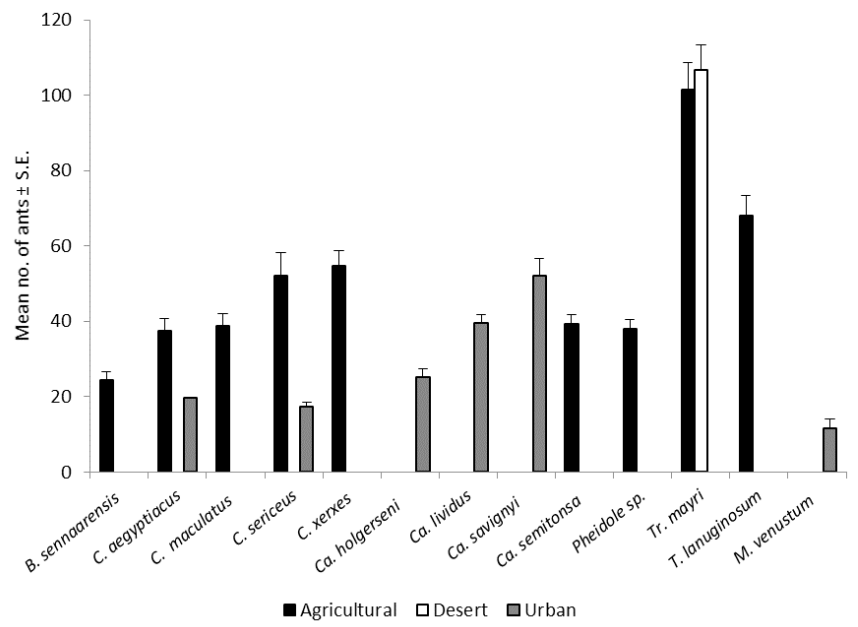

Fig 3. Abundance of ants according to the habitat in Riyadh, Saudi Arabia from May to July (2014). 
Table 1. Ant attracted to the rabbit carcasses in three different habitats.

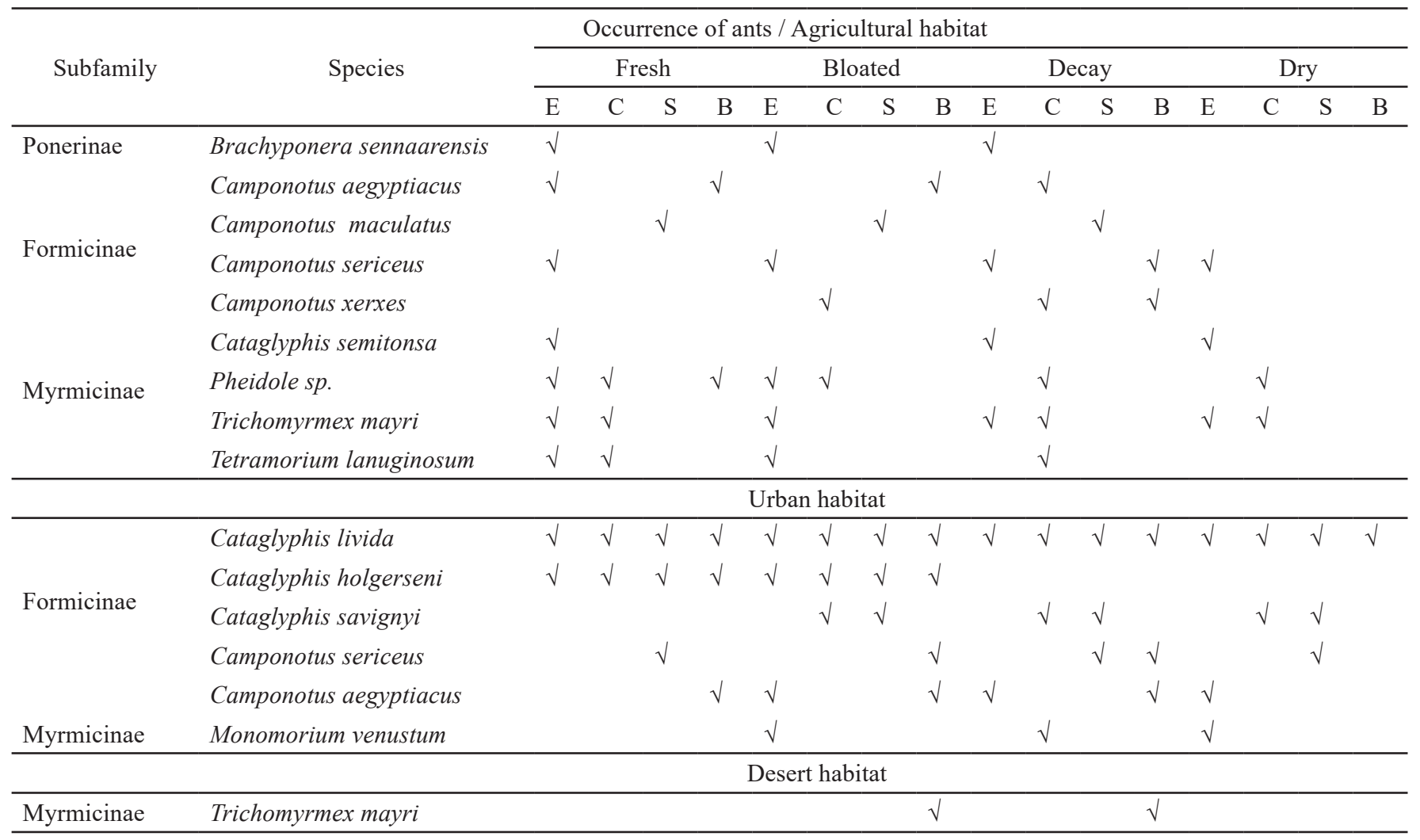

E: Exposed, C: Clothed, S: Shaded, B: Burnt

$\checkmark$ : Presence of ant

attracted in significantly higher numbers than the other ants, followed by Ca. livida, Ca. holgerseni and M. venustum. Camponotus aegyptiacus was attracted significantly lower numbers that the other species (Fig 3). The species richness of ant species showed significant difference among the three habitats (Kruskal-Wallis test, table 2).

In the fresh stage, all ant taxa were represented except C. xerxes, Ca. savignyi and M. venustum. Tetramorium lanuginosum was the most abundant species attracted to the fresh stage. In the bloated stage, only Ca. semitonsa was not attracted. In the bloat stage, Trichomyrmex mayri was the most abundant species collected (Fig 4). In the active decay stage, all of the ant taxa reported here were present, with the exception of Ca. holgerseni. Camponotus xerxes and $C$. aegyptiacus were attracted in a higher numbers in this stage.

Table 2. Kruskal-Wallis test results.

\begin{tabular}{lllll}
\hline Comparison & $\begin{array}{l}\text { Kruskal-Wallis } \\
\text { Test Statistic }\end{array}$ & d.f. & P-Value & Notes \\
\hline $\begin{array}{l}\text { No. of ant species } \\
\text { by Habitat }\end{array}$ & 9.57 & 2 & 0.008 & $*$ \\
$\begin{array}{l}\text { No. of ant species by } \\
\text { decomposition stage }\end{array}$ & 6.74 & 3 & 0.081 & NS \\
$\begin{array}{l}\text { No. of ant species } \\
\text { by carcass status }\end{array}$ & 3.74 & 3 & 0.291 & NS \\
\hline
\end{tabular}

*; Significant, NS; Not significant $(\alpha=0.05)$.
In the dry stage, only six ant species were still present, $C$. sericeus, Ca. livida, Ca. savignyi, Ca. semitonsa, Pheidole sp. and Tr. mayri, the latter being the most abundant (Fig 4). The Kruskal-Wallis test indicated that there were no significant differences in the number of ant species between the different stages of decomposition (Table 2).

The exposed and clothed rabbit carcasses attracted the greatest number of ants (237 and 289, respectively). In contrast, the burnt and shaded rabbit carcasses attracted relatively few ants (98 and 101, respectively). All species

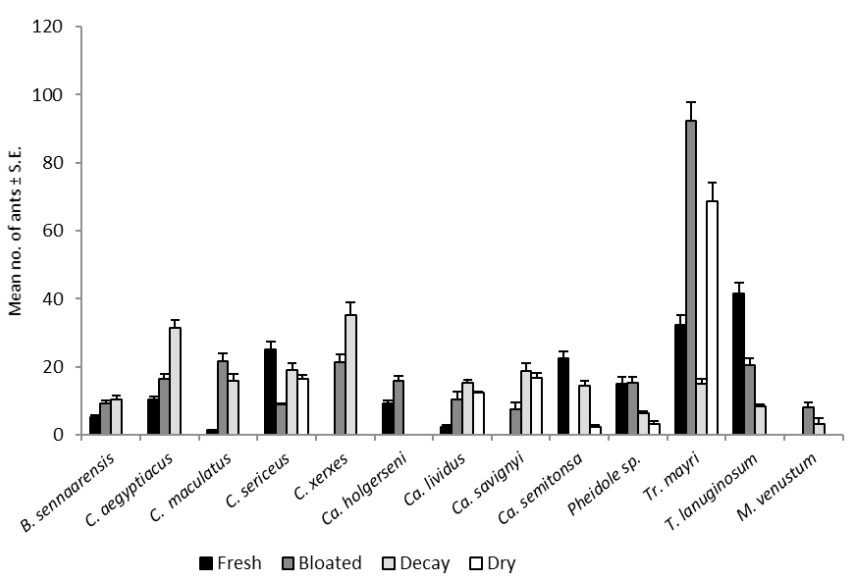

Fig 4. Abundance of ants according to the decomposition stage of rabbit carcasses placed at the three habitats in Riyadh, Saudi Arabia from May to July (2014). 
of ants were attracted to the exposed carcasses (control and clothed carcasses), except $C$. maculatus, C. xerxes, Ca. savignyi and M. venustum. Brachyponera sennaarensis, C. maculatus, $C$. sericeus and $C a$. semitons $a$ were not apparently attracted to the clothed carcasses (Fig 5). Only C. maculatus, C. sericeus, $C a$. livida, Ca. savignyi and $M$. venustum were attracted to the shaded carcasses. The burnt carcasses attracted $C$. aegyptiacus, $C$. sericeus, C. xerxes, Ca. livida, Ca. savignyi, Pheidole sp. and Tr. mayri. Brachyponera sennaarensis and $C a$. semitonsa were present only on exposed carcasses and C. maculatus was only attracted to shaded carcasses (Fig 5). Also, no significant difference in the number of ant species was indicated among the different carcass status using the Kruskal-Wallis test, table 2).

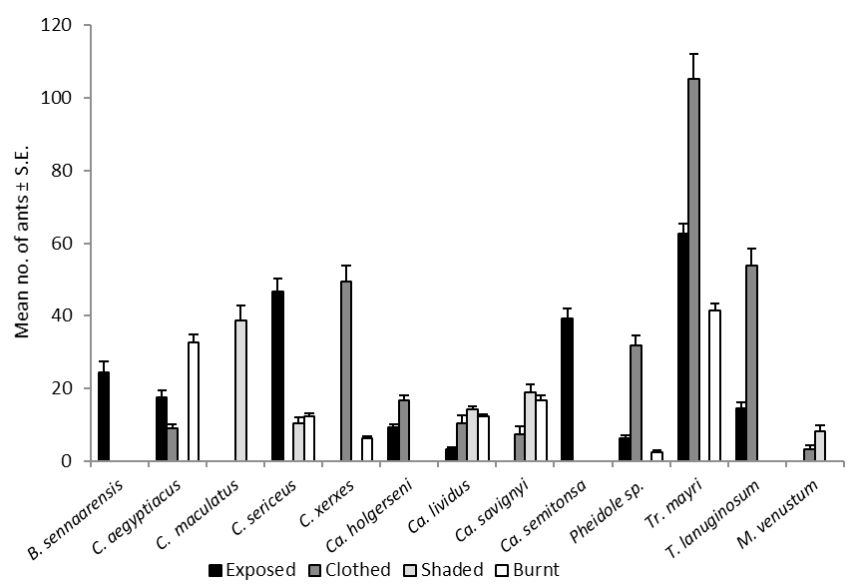

Fig 5. Abundance of ants according to the condition if the carcasses placed at the three habitats in Riyadh, Saudi Arabia from May to July (2014).

\section{Discussion}

In forensic entomological studies, ants attracted to corpses are categorized as omnivorous species (Tabor et al., 2005). Ants can feed on both the corpse and associated fauna. Luederwaldt (1926) reported collecting several species of ants from vertebrate carrion. In addition, Smith (1986) reported that, in the context of forensic entomological analyses, ants are considered to be predators. Throughout our study period, ants were observed actively preying upon the eggs, larvae and newly emerged flies of Calliphoridae, Muscidae and Sarcophagidae. Campobasso et al. (2009) and Chen et al. (2014) reported similar observations. Mashaly et al. (2013) stated that $B$. sennaarensis preferred proteinaceous food over other types of food. Carpenter ants of the genus Camponotus are generally considered to be predators (Sanders \& Pang 1992), and others feed on live and dead arthropods (Dejean, 1988). Although Sharaf et al. (2016) recorded workers of Tr. mayri in areas rich in decaying organic matter. In our study, we recorded ants on the carcasses from shortly after placement during the early post-mortem period and in all the subsequent stages of decomposition, apart from the dry stage.
We did not observe ants feeding directly on the carcasses, but rather, feeding only on the immature stages of flies (Lucilia sericata Meigen, Musca domestica L. and Sarcophaga hirtipes Wiedemann) during the succession process, as has also been reported in the studies of Campobasso et al. (2004), Heo et al. (2009), Nazni et al. (2011) and Chen et al. (2014).

Smith (1986) stated that, habitat and ambient temperatures are important factors that determine the composition and structure of carrion fauna. In our study, high air temperatures affected the rates of decomposition at all study sites. Almost complete decomposition of the rabbit carcasses took six days in the desert and urban sites and about 12 days at the agricultural site. Similar results were reported by Mashaly (2016). Anderson (2009) indicated that the length of time it takes for decomposition to complete is very variable, depending on a number of parameters, including geographical region.

Abou Zied (2014) conducted a decomposition study in the southwestern mountains of KSA and found that the rate of decomposition of rabbit carcasses was affected by high temperature (about $30^{\circ} \mathrm{C}$ ). In Kuwait, Al-Mesbah et al. (2012) illustrated that carcasses at an urban site were found to decompose significantly faster than in the agricultural, coastal or desert sites (as measured by percentage weight loss).

Throughout the course of the study, a total of 726 ants were identified as being attracted to the rabbit carcasses. The agricultural site attracted a significantly higher number of ants compared to the desert and urban sites. Al-Mesbah et al. (2012) did not collect ants from rabbit carcasses at an urban site in Kuwait. We recorded only one species of ant from the carcasses placed at the desert site, but nine and six species of ants from the agricultural and urban sites, respectively. This may be due to the high temperature and relatively barren substrate of the desert site. Trichomyrmex mayri is the most prevalent species compared with other species in all habitats and this is consistent with Sharaf et al. (2016), who said that T. mayri is the most widely-distributed species in the Arabian peninusla. The differences in diversity and numbers of ants attracted to the carcasses in the three different habitats are probably due to the differences in biogeoclimatic zones or ecozones as each habitat was very different (Anderson, 2009). Conditions in the desert habitat are very extreme and only species highly adapted to the high temperatures and arid conditions are able to survive there. The ant species richness is sensitive to plant cover and diversity (Morrison, 1998), soil type (Peck et al., 1998).

In our study, no differences were found in the rate of decomposition between the four types of exposure (exposed, shaded, clothed, and burned) during the study time. Heo et al. (2008), Gruenthal et al. (2012). Mashaly (2016) reported that burning not to have an effect on the rate of decomposition but to have an effect on insect succession. Beckerdite et al. (2014) found that burning chicken carcasses accelerated the decomposition process and affected the succession of insects on the bodies. Clothes can increase the rate of decomposition 
and insect activity (Mann el al., 1990; Campobasso et al., 2001), although Anderson (2009) said that clothes slowed the decomposition and the insect succession, whereas Kelly et al. (2009) found no difference in the succession of insects between unclothed and clothed carcasses. Castro et al. (2011) found a significant effect of the interaction between the decomposition stage and insolation regime. Carcasses exposed to the sun decompose faster than the ones in the shade (Shean et al., 1993; Joy et al., 2006) and show different patterns of insect succession (Sharanowski et al., 2008). Anderson (2009) reported that clothing cadavers affects relative humidity and provides protection for some insects, which may increase insect abundance and diversity. In contrast, Matuszewski et al. (2015) reported that clothing has little importance when considering insect abundance and diversity.

Also, ant species differ according to the condition of the carcass. Some ant species were restricted by the treatment types. For example, B. sennaarensis and Ca. semitonsa were only attracted to the exposed carcasses and $C$. maculatus only to the shaded carcasses. Heo et al. (2009) reported six species of ants associated with pig carcasses placed on the ground. Oecophylla smaragdina (Fabricius) was collected only from the burned carcass and was found throughout decomposition, Tetramorium sp. was only collected from the burned carcass but only in the dry remains stage, whereas Odontoponera sp., Diacamma sp. and Anoplolepis gracilipes F. Smith were specific to the unburned carcass; $A$. gracilipes was found only in the fresh and bloated stages and Odontoponera sp. and Diacamma sp. only in the fresh and dry remains stage. Pheidologeton sp. was the only species found on both burned and unburned carcasses, primarily in the dry remains stage (Heo et al., 2009). As in our study, Heo et al. (2009) reported that the ants predated on fly larvae. Kolver (2009) stated that ants preyed on the fly eggs, fly larvae and adult beetles, but also fed on the burnt skin and soft tissue of the burnt carcasses, causing feeding damage in the form of a characteristic pitted appearance formed by the removal of minute portions of tissue.

In conclusion, this is the first study to report the species of ants that are attracted to rabbit carcasses exposed in four different conditions (exposed, clothed, shaded and burnt) and in three different sites (agricultural, desert and urban) in Riyadh, KSA. The study recorded a total of 726 ants belonging to three subfamilies and 14 species. The agricultural site attracted the highest number of ants. Trichomyrmex mayri was the most abundant species in both the agricultural and desert sites. Decomposition stage or the carcass status did not effect on the number of ants attracted.

\section{Acknowledgements}

The authors extend their appreciation to the Deanship of Scientific Research at King Saud University for funding the work through the research group project no. RGP- 028. The authors are indebted to Dr. Boris Kondratieff (Colorado State University) for valuable comments.

\section{References}

Abou Zied, E.M. (2014). Insect Colonization and Succession on Rabbit Carcasses in southwestern Mountains of the Kingdom of Saudi Arabia. Journal of Medical Entomology 51(6): 1168-1174.

Al-Mesbah, H.C., Moffatt, O.M.E., El-Azazy, C. \& Majeedd, Q.A.H. (2012). The decomposition of rabbit carcasses and associated necrophagous Diptera in Kuwait. Forensic Science International, 217: 27 - 31.

Anderson, G.S. (2009). Factors that influence insect succession on carrion. In: Byrd JH, Castner JL (eds.) Forensic entomology: The utility of arthropods in legal investigations. 2nd ed. Boca Raton, FL: CRC Press, pp. 201 - 250.

Beckerdite, H., Hundl, C., Ingle, E., McStravick, K., Turman, L. (2014). The effect of burning on cadaver decomposition and insect succession. Instars: A Journal of Student Research, 1: $149-151$.

Bolton, B. (1994). Identification Guide to the Ant Genera of the World; Harvard University Press: Cambridge.

Byrd, J.H. \& Castner, J.L. (2001). Forensic Entomology. The utility of arthropods in legal investigations. CRC Press. Boca Raton, Florida.

Campobasso, C.P., Di Vella, G. \& Introna, F. (2001). Factors affecting decomposition and Diptera colonization, Forensic Science International, 120:18-27.

Campobasso, C.P., Di Vella, G. \& Introna, F. (2001). Factors affecting decomposition and Diptera colonization. Forensic Science International, 120: 18 - 27.

Campobasso, C.P., Marchetti, D. \& Introna, F. (2004). Postmortem artifacts made by ants and the effect of ant activity on decompositional rate. European Association for Forensic Entomology. Second Meeting. United Kingdom.

Campobasso, C.P., Marchetti, D., Introna, F. \& Colonna, M.F. (2009). Postmortem artifacts made by ants and the effect of ant activity on decompositional rates. American Journal of Forensic Medicine and Pathology, 30: 84 - 87.

Card, A., Cross, P., Moffatt, C. \& Simmons, T. (2015). The Effect of Clothing on the Rate of Decomposition and Diptera Colonization on Sus scrofa Carcasses. Journal of Forensic Sciences. 60: 979 - 82 .

Castro, C.P., Sousa, J.P., Arnaldos, M.I., Gaspar, J. \& Garcia, M.D. (2011). Blowflies (Diptera: Calliphoridae) activity in sun exposed and shaded carrion in Portugal. Annales- Societe Entomologique de France, 47: 128 - 139.

Catts, E.P., N.H. Haskell, 1990. Entomology and death: a procedural guide, Joyce's Print Shop, Inc.: Clemson.

Chen, C.D., Nazni, W.A., Lee, H.L., Hashim, R., Abdullah, N.A., Ramli, R., Lau, K.W., Heo, C.C., Goh, T.G., Izzul, 
A.A. \& Sofian-Azirun, M. (2014). A preliminary report on ants (Hymenoptera: Formicidae) recovered from forensic entomological studies conducted in different ecological habitats in Malaysia. Tropical Biomedicine 31: 381-386.

Collingwood, C.A. (1985). Hymenoptera: Fam. Formicidae of Saudi Arabia. Fauna of Saudi Arabia, 7: 230-301.

Collingwood, C.A. \& Agosti, D. (1996). Formicidae (Insecta: Hymenoptera) of Saudi Arabia (part 2). Fauna of Saudi Arabia, 15: 300-385.

Dejean, A. (1988). Prey capture by Camponotus maculatus (Formicidae: Formicinae). Biology of Behaviour, 13: 97-115.

Gennard, D.F. (2007). Forensic entomology: An introduction, 2nd Ed. John Wiley-Blackwell, Hoboken, NJ.

Glassman, D. \& Crow, R. (1996). Standardization Model for Describing the Extent of Burn Injury to Human Remains. Journal of Forensic Sciences, 41: 152-154.

Goddard, J. \& Lago, P.K. (1985). Notes on blowfly (Diptera: Calliphoridae) succession on carrion in Northern Mississippi. Journal of Entomological Sciences, 20: 312-317.

Gruenthal, A., Moffatt, C. \& Simmons, T. (2012). "Differential Decomposition Patterns in Charred Versus UnCharred Remains". Journal of Forensic Sciences 57: 12-18.

Gunn, A. (2006). Essential Forensic Biology. John Wiley and Sons Ltd. England.

Heo, C.C., Marwi, M.A., Salleh, A.F.M., Jeffery, J., Kurahashi, H. \& Omar, A. (2008). Study of insect succession and rate of decomposition on a partially burned pig carcass in an oil palm plantation in Malaysia. Tropical Biomedicine, 25: 202-208.

Heo, C.C., Marwi, M.A., Hashim, R. Abdullah, N.A., Dhang, C.C., Jeffery, J., Kurahashi, H. \& Omar, B. (2009). Ants (Hymenoptera: Formicidae) associated with pig carcasses in Malaysia. Tropical Biomedicine, 26: 106-109.

Hölldobler, B. \&Wilson, E.O. (1990). The Ants. Harvard University Press: Cambridge.

Joy, J.E., Liette, N.L. \& Harrah, H.L. (2006). Carrion fly (Diptera: Calliphoridae) larval colonization of sunlit and shaded pig carcasses in West Virginia, USA. Forensic Science International 164: 183 - 192.

Keller, L. \& Gordon, E. (2009). The Lives of Ants. Oxford University press. Inc., New York.

Kelly, J.A., Linde, T.C.V.D. \& Anderson, G.S. (2009). The influence of clothing and wrapping on carcass decomposition and arthropod succession during the warmer seasons in Central South Africa, Journal of Forensic Sciences, 54: 1105-1112.

Kolver, J.H. (2009). Forensic Entomology: The influence of the burning of a body on insect succession and calculation of the postmortem interval. $\mathrm{PhD}$ thesis, University of the Free State.
Lindgren, N.K., Bucheli, S.R., Archambeault, A.D. \& Bytheway, J.A. (2011). Exclusion of forensically important flies due to burying behavior by the red imported fire ant (Solenopsis invicta) in southeast Texas. Forensic Science International, 204: e1 - e3.

Luederwaldt, H. (1926). Observações biologicas sobre formigas brasileiras especialmente do estado de São Paulo. Revista do Museu Paulista, 14: 185-303.

Mann, R., Bass, W. \& Meadows, L. (1990). Time since death and decomposition of the human body: variables and observations in case and experimental field studies, Journal of Forensic Sciences, 35: 103-111.

Mashaly, A.M.A. (2016). Entomofaunal succession patterns on burnt and unburnt rabbit carrion. Journal of Medical Entomology, 53: 296-303.

Mashaly, A.M.A., Al-Mekhalfi, F.A. \& Al-qahtani, A.M. (2013). Food Preferences and Foraging Activity of Field Populations of a Samsum Ant, Pachycondyla sennaarensis. Bulletin of Insectology, 62: 187-193.

Matuszewski, S., Frątczak, K., Konwerski, S., Bajerlein, D., Szpila, K., Jarmusz, M., Szafałowicz, M., Grzywacz, A. \& Mądra, A. (2016). Effect of body mass and clothing on carrion entomofauna. International Journal of Legal Medicine, 130: 221-32.

Matuszewski, S., Konwerski, S., Frątczak, K. \& Szafałowicz, M. (2014). Effect of body mass and clothing on decomposition of pig carcasses. International Journal of Legal Medicine 128: 1039-1048.

Moretti, T.C., Giannotti, E., Thyssen, P.J., Solis, D.R. \& Godoy, W.A.C. (2011). Bait and habitat preferences, and temporal variability of social wasps (Hymenoptera: Vespidae) attracted to vertebrate carrion. Journal of Medical Entomology, 48: 1069-1075.

Moretti, T.C. \& Ribeiro, O.B. (2006). Cephalotes clypeatus Fabricius (Hymenoptera: Formicidae): nesting habits and occurrence in animal carcass. Neotropical Entomology, 35: $412-415$.

Morrison, L.W. (1998). The spatiotemporal dynamics of insular ant metapopulations. Ecology. 79: 1135-1146.

Nazni, W.A., Lee, H.L., Chen, C.D., Heo, C.C., Abdullah, A.G., Wan-Norjuliana, W.M., Chew, W.K., Jeffery, J., Rosli, H. \& Sofian-Azirun, M. (2011). Comparative insect fauna succession on indoor and outdoor monkey carrions in a semiforested area in Malaysia. Asian Pacific Journal of Tropical Biomedicine, 1: S232-S238.

Payne, J. (1965). A summer carrion study of the baby pig Sus scrofa Linnaeus. Ecology 46: 592-602.

Peck, S.L., McQuaid, B. \& Campbell, C.L. (1998). Using ant species (Hymenoptera: Formicidae) as a biological indicators 
of agroecosystem condition. Environmental Entomology. 27: 1102-1110.

Sanders, C.J. \& Pang, A. (1992). Carpenter ants as predators of spruce budworm in the boreal forest of northwestern Ontario. Canadian Entomology, 124: 1093-1100.

Shaalan, E.A., El-Moaty, Z.A., Abdelsalam, S. \& Anderson, G.S. (2017). A Preliminary Study of Insect Succession in AlAhsaa Oasis, in the Eastern Region of the Kingdom of Saudi Arabia. Journal of Forensic Sciences 62: 239-243.

Sharaf, M.R., Salman, S., Al-Dhafer, H.M., Akbar, S.A., Abdel-Dayem, M.S. \& Aldawood, A.S. (2016). Taxonomy and distribution of the genus Trichomyrmex Mayr, 1865 (Hymenoptera: Formicidae) in the Arabian Peninsula, with the description of two new species. European Journal of Taxonomy, 246: 1-36.

Sharanowski, B.J., Walker, E.G. \& Anderson, G.S. (2008). Insect succession and decomposition patterns on shaded and sunlit carrion in Saskatchewan in three different seasons. Forensic Science International, 179: 219-240.

Shean, B.S., Messinger, L. \& Papworth, M. (1993). Observations of differential decomposition on sun exposed v. shaded pig carrion in coastal Washington-State. Journal of Forensic Sciences, 38: 938-949.
Shi, N.N., Tsai, C.C., Camino, F., Bernard, G.D., Yu, B.N. \& Wehner, R. (2015). Keeping cool: Enhanced optical reflection and radiative heat dissipation in Saharan silver ants. Science, 349: 298-301

Silahuddin, S.A., Latif, B., Kurahashi, H. \& Heo, C.C. (2015). "The importance of habitat in the ecology of decomposition on rabbit carcasses in Malaysia: Implications in forensic entomology." Journal Medical Entomology, 52: 9-23.

Sleigh, C. (2003). Ant. Animal, Series editor: Jonathan Burt. Rreaktion books ltd.UK.

Smith, K.G.V. (1986). Manual of Forensic Entomology. Cornell University Press, Ithaca.

Tabor, K.L., Fell, R.D. \& Brewster, C.C. (2005). Insect fauna visiting carrion in Southwest Virginia. Forensic Science International, 150: 73-80.

Tantawi, T.I., El-Kady, E.M., Greenberg, B., El-Ghaffar, H.A. \& et al. (1996). "Arthropod succession of exposed rabbit carrion in Alexandria, Egypt.” Journal of Medical Entomology, 33: 566-580.

Taylor, B. (2007). The Ants of (sub-Saharan) Africa. Available at: http://antbase.org/ants/africa/

Voss, S.C., Cook, D.F. \& Dadour, I.R. (2011). Decomposition and insect succession of clothed and unclothed carcasses in Western Australia. Forensic Science International, 211: 67-7 5.

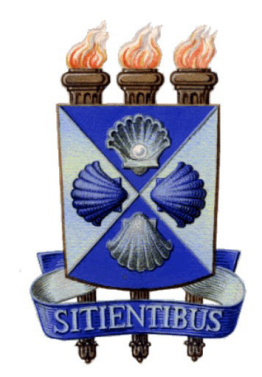

